\title{
CEO Characteristics and Valuation of the Organization: A Quantile Regression Analysis
}

\author{
Muhammad Rizwan Nazir (Corresponding author) \\ PhD Scholar (Finance), School of Finance \\ Zhongnan University of Economics and Law, China \\ E-mail: rizwan.n99@outlook.com
}

Muhammad Imran Nazir

PhD Scholar (Finance), School of Finance

Zhongnan University of Economics and Law, China

Ifran Khan

MS Scholar (Finance), IFAS

Xiamen University, China

Faryal

PMAS Arid Agriculture University Rawalpindi, Pakistan

Received: February 22, 2018

doi:10.5296/ijafr.v8i1.12824
Accepted: March 4, 2018 Published: March 14, 2018

URL: https://doi.org/10.5296/ijafr.v8i1.12824

\begin{abstract}
This study examines the effects of three highly-visible CEO characteristics on a valuation of the organization. Using a sample for Chinese firms over the period of 2007-2016, we find that CEO age is consistently related with lower organizations' valuation. CEO tenure is also related with lower valuation, but more significantly so in the higher quantiles of organizations'
\end{abstract}




\section{MInstitute Macrothink $^{m}$}

International Journal of Accounting and Financial Reporting ISSN 2162-3082

valuation, that is for organizations with high growth opportunities. The CEO duality is found to be valuable only for organizations with high growth opportunities. Overall, this study highlights the contingent association between CEO characteristics and valuation of the organization.

Keywords: CEO Characteristics, CEO age, CEO duality, CEO tenure, Performance, Quantile Regression, Chinese firms

\section{JEL Classifications: C21, G30, G34}

\section{Introduction}

Financial economists have always paid considerable interest to the role of chief executive officer (CEOs) and closely monitor the performance of firms as well as the performance of CEOs, because they have substantial influence on the strategic decisions and outcomes of their firms (Daily, 1997; Johnson, 1997; Finkelstein, 1994; Kim, 2016). According to Zahra and Pearce, (1989) CEO powers are enhanced by the control of organization's top decision making group, but still which CEO characteristics matter for firm's performance? Among the other all visible traits only three have been extensively discussed in management literature age, tenure and duality often with the mixed results. The present study investigates the link between these characteristics and firm evaluation, representing a measure of the firm's long-term performance. In this study we will investigate those CEO characteristics especially age and duality which are ignored in previous studies due to their extreme conditional effects.

The recent studies advocate that older CEOs are more vigilant and tend to follow conservative strategies which leads to lower spending on R\&D (Barker, 2002) and show least interest by adopting of new technologies (Kitchell, 1997). The psychological experiments point out that with the passage of age as people grow up they became less flexible. According to Vroom (1971), age is associated with more risk aversion. Child (1975) contends that younger CEOs are able to do more physical and mental efforts, consequently challenging the status quo and promoting change and growth in their companies. The argument that younger CEOs tried to adopt new strategies to get better future firm performances intrinsically leads to the 'horizon problem' (Mason, 1984). The CEO's career horizon problem is the function of CEO's age. Whereas younger CEO's with extended career horizon are adopting more risky strategies with comparison of those older CEO's having less career horizon and more advantageous to their jobs and adopting risk averse strategies in resulting low growth of the firm. In fact, some studies have endorsed the fact that with the shorter career horizon CEOs hold back the risky strategies, like Research and development expenditures and international acquisitions (Barker, 2002; Matta, 2008).

The longer CEO tenure can also lead to greater conservatism and status-quo bias, but replacement of CEO is a significant event in the history of any organization because it has remarkable implication on future organizational strategic direction and success. Meanwhile longer tenure CEOs have vital potential drawbacks but there are also many offsetting merits from longer experience and knowledge of the firm come to pass from longer tenure mitigating the negative effects. The experimental confirmation from (Miller, 1991; 


\section{Ml Macrothink}

International Journal of Accounting and Financial Reporting

ISSN 2162-3082

2018, Vol. 8, No. 1

McClelland et al., 2012) advocate that rapid change in CEO position are resulting in negative firm performance perhaps facing uncertain and rapid changing environment. Henderson et al., (2006) contend that CEO can enjoy longer tenure only in stable environment. Anyhow it obviously becomes unfavorable when firms environment are fast changing.

The consequences of CEO duality are more disputed among other characteristics. On the one perspective, agency theory advocates that CEO duality may restrict board monitoring (Allegrini, 2013) and spoil the boards capacity to replace a bad performing CEO (Park, 2002). On the other side, stewardship theory advises that CEO duality creates a vital line of power within the firm and reduce the possible executive conflict and political intrigue (Finkelstein, 1994). It also increases the effectiveness of decision making process Finkelstein (1994), which leads to increase the organizational efficiency. This ought to result in high firm valuation, particularly when firms are in front of external environmental challenge (Kang, 2005).

The previous empirical work found mixed results regarding CEO characteristics because they assume that the effect of CEO characteristics to be homogenous across the firms and no affected by outliers. We use Quantile regression analysis which is particularly appropriate when the data have some outliers or when the OLS regression residuals are not distributed normally (e.g., when the residuals have asymmetric, fat-tailed or truncated distribution). Since dispersion is measured by absolute deviation instead of squared deviation, Quantile regression is less sensitive to outliers. Quantile regression also allows the effect of the explanatory variables to be evaluated at various quantiles of the conditional dependent variable, thus allowing the detection of potential heterogeneity in the effects of the focal variables. In our case, it allows to distinguish the effects in high growth (i.e., high valuation) firms from those in low-growth (i.e., low valuation) firms. Indeed, prior research indicates that the effect of CEO characteristics may be contingent on the firm's context, which can be very much described by the richness of the firm's growth opportunities. In this study we investigate the effect of CEO characteristics on firm evaluation with the help of Chinese manufacturing organizations. We propose the Quantile regression method to find out the desired result.

This study is organized as follows: the theoretical and empirical literature is discussed in section 2. Section 3 shows the data and methodology for this paper. The different research models and assessments with a complete interpretation are involved in section 4. Section 5, concludes the paper and explain the results of this study with policy implications and recommendations for further research.

\section{Literature Review and Hypothesis Development}

A vast array of extant literature exists on CEO's Characteristics. In result CEOs are expected to have a significant impact on firm's performance given the influence they have over critical decisions. The instinctive abilities (which are hard to observe) and apparent characteristics (likewise age, tenure, duality) make the difference in between CEOs. 


\section{$\Lambda$ Macrothink}

International Journal of Accounting and Financial Reporting ISSN 2162-3082

The previous theoretical work predicts that a CEO's age impact on his risk preferences and risk taking behavior, but results are mixed. Specifically, models incorporating career concerns predict that younger CEOs are more risk averse because they do not yet have reputations as high quality managers (Hirshleifer, 1993). As such, younger CEO's can be punished more harshly for poor performance through markedly reduced future career opportunities, which can induce them to adopt more conservative investment policies. In contrast, Stole (1996) developed a model that predicts that younger CEOs invest more aggressively and take greater risks to signal superior ability. In particular, younger CEOs overweight their personal beliefs and exaggerate their investment behavior to appear talented.

The influence of the decision maker's age has long been a topic of intense debate in management studies. The possible effect of CEO's age on a firm's performance has got attention in the literature, as it can be assumed that older CEO's have a competitive advantage compared to younger, who inevitably have less experience in business. While experienced managers may help to improve the firm's performance. They also likely to be reluctant and are flat follower to the status quo. Vroom and Pahl (1971) documented a negative relationship between age and risk taking behavior. Whereas some studies find strong relationship among young management and firm growth (Child, 1975).

Matta and Beamish (2008) advocate that vigilant behavior of older CEO's stem from their shorter decision horizon. They give priority to the short term projects when they are near to retirement. Davidson et al., (2007) examined the impact of CEO's career horizon on the firm's earning management and surprisingly found that age have large discretionary accruals in the year before their retirement. Gibbons and Murphy (1992) supported that those projects got the attention of CEOs which are payoff before their retirements. Similarly Hirshleifer (1993) contend that younger CEOs may also focus to invest in short term projects in start of their career to build good reputation in front of management. So, prior literature generally talk about the impact of executive age which may influence on firm performance but with mixed results.

The risk taking is a significant step for a firm's profitability and future growth. We suppose CEO age to be detrimental to long-term firm performance and valuation. Consistent with this idea, Serfling (2014) proposed that firms with older CEOs having less risky investment policies in result lower stock return volatility specifically lower R\&D investments, diversifying acquisitions, and lower operating leverage. Whenever firms replaced young CEO with older one the market react negatively. So we propose following hypothesis for CEO's age:

\section{Hypothesis 1: CEO age is associated with lower firm valuation.}

While Tenure and CEOs age are evidently correlated, previous studies argue that CEO tenure may affect the firm's performance in different ways, because the performance of a CEO at age of 60 in a tenure of 5 years is definitely different from age of 50 years in same tenure. Miller (1991) found that firms having long tenured CEOs is weaker in firm's strategy and its environment because they are rigid and believe to maintain status quo. Consistent with this 


\section{Mll Macrothink}

International Journal of Accounting and Financial Reporting ISSN 2162-3082 2018, Vol. 8, No. 1

view, his results showed inverse relationship in contrast with CEO tenure and firm's performance. So, longer CEO tenure come into sight to hurt firm performance.

The agency theory channel is another aspect of inverse relationship between CEO tenure and negative firm's performance. According to (Morck, 1988) long tenure CEOs having their personal relationship with the board members and less likely to be disciplined for poor performance. In the light of same concept Hermalin and Weisbach (1991) show that performance, measured by Tobin's Q, decreases with CEO tenure.

McClelland et al., (2012) contend that the effect of CEO tenure depends on the dynamics of the firm's industry. CEO tenure has a negative influence on future performance in rapidly-changing industries, but not in more stable industries. These results suggest that the negative effect of CEO tenure on long-term performance, and hence valuation of the firm, will be more pronounced in high-growth firms, which typically face a more uncertain future. We propose the following hypothesis regarding CEO tenure.

Hypothesis $2_{A}$ : CEO tenure is correlated with lower firm valuation.

Hypothesis $2_{B}$ : The negative effect of CEO tenure on firm valuation is stronger in firms with more growth opportunity, as they face a more uncertain and changing environment.

The existing literature addresses the CEO Duality in two different ways. The agency theory argues that CEO duality leads to entrenchment and a weak, ineffective board and reducing the performance potential of the firm. On the other hand the stewardship advocates in favor of CEO duality which increases board effectiveness by concentrating power and controlling conflicts within the board. Park (2002) supported the deteriorates association between firm performance and CEO termination. This imitates the independence of board and place it under the control of CEO. Bhagat and Bolton (2008) finds that the duality is negative correlated with firm's performance and firm's valuation.

On the other hand stewardship theory highlight the significant benefits of CEO duality. It decreases the internal and external conflicts of board (Finkelstein, 1994). Moreover duality gives the power to the CEO for running the firm's operations and taking decisions quickly and the line of reporting authority is with single person which leads to the greater organizational effectiveness (Henderson, 2006).

The board of directors is "at the peak of internal control system, has the final responsibility for the functioning of the firm" (Jensen, 1993). However, when the board chairman is also the CEO, The board strength to monitor and supervise the management is reduced as a result of lack of independence and a conflict of interest (Lorsch, 1989). The issue that arises when companies put into practice CEO duality is "who monitors management?" This is best expressed as, "custodies" or "who will watch the watchers." Unlike in a two tier system, the unitary system has the boards at the highest internal control system as argued by (Jensen, 1993). It has been argued that the firm's managers' influence in setting board agenda and controlling information flows could impede the board's ability to perform its duties effectively (solomon, 1993). The firm's managers' ability to determine the board agenda and flow of information is predicted to be much stronger when the board chairman is also CEO 


\section{MInstitute ${ }^{\text {Mink }}$}

International Journal of Accounting and Financial Reporting

ISSN 2162-3082

2018, Vol. 8, No. 1

than when the firm adopts a non-dual structure. Daynton (1984) supported that the board is the primary force pushing the company towards realizing the opportunities and meeting the obligations to the shareholders and other stakeholders. He explained that it is the CEO who enable the board to play the primary force.

In a similar way, dual leadership structure "signals the lack of separation on the decision management and the decision control" (Jensen, 1993). Rechner (1991) argued that the ideal corporate governance structure in which the board is composed of a majority of outside directors and a chairman who is an outside director. She declared that the weakest corporate governance structure is one where the board is dominated by insider directors and the CEO holds the chairmanship of the board. When one person dominates a firm, the role of independent outside directors becomes "hypothetical". Renchner (1989) claimed, "This structure is likely to function as a rubber stamp board given the total control of the CEO". A structure of this type is likely to lead to the board being incapable of protecting the interest of the shareholders.

The issue of separation of the top two post has been addressed in the Cadbury committee, which recommended that the roles of the board chairman and the CEO be separated. The need of separation is that when both the monitoring roles and implementation role are vested in a single person, the monitoring roles of the board will be severely impaired. The impairment in the board independence could affect the board incentives to ensure that management purses value increasing activities. Hampel (1998) point out that in some circumstances, the top two roles can be combined, but it recommends that the reasons for combining the roles be publicly disclosed. Though the literature seems to consistently argue that separate individuals for the post of CEO and chairman leads to a better corporate governance system, the real issue is whether this leads the board to be a better monitor and, thus, is capable of increasing the value of the firm. The supporters of the CEO duality structure argue that combining the two roles provides a clear focus for objectives and operations (Finkelstein, 1994).

The effect of CEO duality on firm's performance rely on the internal and external structure of the firm (Boyd, 1995). In the high growth sector firms face more uncertainties and challenges whereas low growth firms are more certain.

Based on these arguments, we propose the following hypothesis:

Hypothesis $3_{A}$ : CEO duality is associated with lower firm valuation.

Hypothesis $3_{B}$ : CEO duality is more strongly associated with lower firm valuation in firms with fewer growth opportunities.

Hypothesis $3_{C}$ : CEO duality is associated with higher firm valuation.

Hypothesis $3_{D}$ : CEO duality is more strongly associated with higher performance in firms with more growth opportunities. 


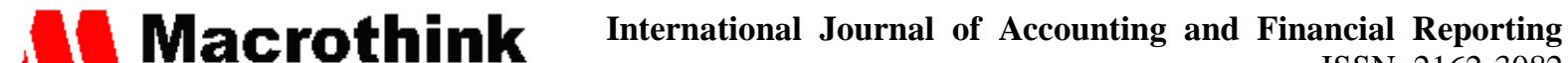 ISSN 2162-3082 2018, Vol. 8, No. 1}

\section{Data and Methodology}

\subsection{Data Sample}

The sample consists of the manufacturing companies listed on the Shanghai Stock Exchange, China for the time period 2007-2016. We have selected the sample from publicly listed organizations for the reason that of the market capitalization and the top firms in China. We have collect data on 60 manufacturing firms for a 10 years' time period and the main data comes from the China Stock Market \& Accounting Research (CSMAR) data base.

\subsection{Econometric Strategy}

To measure the firm valuation, this study use Tobin's Q. This variable is calculated by the ratio of market value of equity plus total liabilities over the book value of the assets. We take the natural $\log$ of the Tobin's Q to alleviate the adverse effect concerning to its positive skewness (Barontini and Caprio, 2006; Adams and Ferreira, 2009). The organizations with maximum Tobin's Q are generally related with more growth opportunities. Meanwhile the correlation investigation emphasizes the effect of the organizations governance structure and the financial features on its market estimation, this study use multivariate regression to examine the relation between CEO characteristics and the firm valuation. The variables of concentration are CEO duality, tenure, and age. CEO age is the number of years since the CEO was born. CEO duality is a dummy variable that equals one if the CEO is also the chairperson of the board, and zero otherwise. The CEO tenure is the number of years the CEO has been in the same position.

The multivariate regressions consist a number of control variables that are anticipated to affect an organizations valuation. Three variables are incorporated to the structure of the organization's governance: board independence, ownership, and size. The board size is measured by the number of directors in a particular board. As for as concern to the larger boards are substance to larger the management problems to handle the different situations and ultimately there is negative influence on a firm valuation (Jensen, 1983; Yermack, 1996). The board independence is measured by the ratio of independent directors over the total number of directors in a particular board. The independent boards are more probable to terminate the CEO in case of the poor performance which leads to the poor valuation of the organizations, whereas the organization with more board independence are more suspicious at selecting and paying for acquisitions objects (Weisbach, 1988; Byrd and Hickman, 1992; Nazir et al., 2016). The board ownership is calculated by the proportion of shares mutually held by all board members. This ownership emboldens inspections and should lead to the more valuation of the organizations. The board ownership and management is related with the greater organization valuation (Yermack, 1996). The other control variables are asset composition, firm size, leverage and growth rate. The firm size is measured by the natural log of the total assets. As for as the smaller organizations are normally related with the more valuation. The leverage is a current and non-current debt by the total assets. Moreover engendering the more tax savings, the maximum leverage is probable to execute the stricter restraint on the regulatory authorities. 


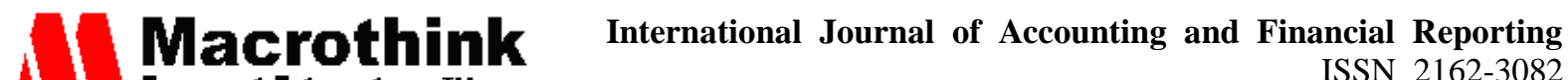 Institute"'

The regression model as follows:

$$
\begin{aligned}
\ln \left(\text { Tobins }^{\prime} S Q\right)= & \alpha_{1} \text { CEO age }+\alpha_{2} \text { CEO tenure }+\alpha_{3} \text { CEO duality }+ \\
& \alpha_{4} \text { Board size }+\alpha_{5} \text { Board independence }+ \\
& \alpha_{6} \text { Board ownership }+\alpha_{7} \text { Firm size }+\alpha_{8} \text { Leverage }+\varepsilon
\end{aligned}
$$

The model is first assessed by OLS regression with standard errors corrected for assembling at the organization level. This method generate the mean conditional effect of each of the independent variables. As for as, it might obscure the potential heterogeneity in the association among CEO characteristics and the organization value. The development of hypothesis in the previous section, the influence of some of our main variables is provisional on the environmental improbability facing the organizations. To examine this contingent influence, a probable methodology may thus to be interrelate each main variable with the Tobin's Q signifying the organizations growth opportunities. Therefore, we apply Quantile regression to examine for such conditional effects. One benefit of Quantile regression is that it is fewer delicate to outliers and normally distributed errors. Therefore the utmost essentially, it might variable. The dependent variable of Tobin's $Q$ has been shown to seizure an organization's future growth opportunities, we suppose that the coefficient of CEO duality and tenure to diverge through the quantiles, subsequently we have assumed that the influence of these variables should diverge through low and high growth organizations. We evaluation the model at the $25^{\text {th }}, 50^{\text {th }}, 75^{\text {th }}$, and $90^{\text {th }}$ quantiles. The lesser quantiles normally show the organizations with low growth valuations, while the higher quantiles usually symbolize organizations with more growth opportunities. Finally, the indication is to examine whether CEO characteristics have difference influence on the high growth valuation firms as compared to the low growth valuation firms.

\section{Empirical Results and Discussion}

\subsection{Descriptive Statistics}

Table 1 shows the descriptive statistics for the sample of this study. The average of CEO age is 43 years. A quarter of CEOs age are younger than 42 years whereas the other quarter are older than 53 years. The average tenure of the CEO is 16.1 years which is one of the average tenure to construct the strategies and implementation which ultimately effect on the valuation of the organization. The majority of the organizations have joint leadership structures because the mean value of the CEO duality is 0.600 . In fact the mean value of the independent directors is 0.401 which are sitting on their boards. The average board size of a particular organization is 7.700. Board ownership explains a positive skewness, whereas the mean is about $5.7 \%$ and the median value is $1.96 \%$. Table 2 investigates the relationship of the selected variables, which shows there is no multicolinearity issue between the variables in this study. Figure 1 shows the graphical presentation of the three CEO characteristics with the performance valuation (Tobin's Q). Figure 2 explains the graphical presentation of the Tobin's Q of all the organizations. 


\section{MlMacrothink}

International Journal of Accounting and Financial Reporting

ISSN 2162-3082

Table 1. Descriptive statistics 2018, Vol. 8, No. 1

\begin{tabular}{lcccccccc} 
& Mean & Std.Dev & CV & Q25 & Q50 & Q75 & Skew & Kurtosis \\
\hline Tobin's Q & & & & & & & & \\
CEO age & 1.129 & 0.381 & 0.337 & 0.484 & 0.846 & 1.497 & 0.124 & 1.731 \\
CEO tenure & 43.000 & 10.732 & 0.249 & 42 & 47 & 53 & 1.659 & 4.831 \\
CEO duality & 16.100 & 1.579 & 0.098 & 17 & 19 & 23 & -1.691 & 4.678 \\
Board Size & 0.600 & 0.490 & 0.816 & 0 & 1 & 1 & -0.408 & 1.166 \\
Board Independence & 7.700 & 1.269 & 0.164 & 8 & 9 & 9 & -0.305 & 1.417 \\
Board Ownership & 0.401 & 0.070 & 0.174 & 0.330 & 0.533 & 0.590 & 0.463 & 1.499 \\
& 5.719 & 1.962 & 0.343 & 4.577 & 6.475 & 9.667 & 0.328 & 1.788 \\
Firm Size & & & & & & & & \\
Leverage & 15.912 & 1.442 & 0.091 & 15.571 & 17.313 & 19.827 & -0.118 & 1.145 \\
\hline
\end{tabular}

Std.Dev denotes the standard deviation; CV show the coefficient of the variation; Tobin's Q is the market equity plus total liabilities to total assets; CEO age is the number of years since the CEO was born; CEO duality show that the CEO is also chairperson of the board; CEO tenure is the number of years since the CEO hold the position; Board independence is the proportion of the independent to total directors; Firm size is the natural log of the total assets; Board ownership is the proportion of shares hold by all the members of the board; Leverage is the total debt over total assets.

Table 2. Correlation between the variables

$$
1
$$

2 3 4 5 6 7 8 9

\begin{tabular}{lcccccccccc} 
Tobin's Q & 1 & 1.000 & & & & & & & \\
CEO age & 2 & -0.043 & 1.000 & & & & & & \\
CEO tenure & 3 & -0.020 & -0.068 & 1.000 & & & & & \\
CEO duality & 4 & 0.039 & 0.220 & 0.012 & 1.000 & & & & \\
Board Size & 5 & 0.023 & 0.021 & -0.002 & -0.034 & 1.000 & & & \\
Board Independence & 6 & 0.016 & 0.026 & 0.084 & 0.025 & -0.342 & 1.000 & & \\
Board Ownership & 7 & 0.071 & 0.018 & 0.029 & 0.104 & 0.058 & 0.004 & 1.000 & \\
Firm Size & 8 & 0.005 & -0.049 & 0.003 & -0.007 & -0.106 & -0.049 & -0.120 & 1.000 & \\
Leverage & 9 & -0.033 & 0.080 & -0.010 & 0.002 & 0.013 & -0.062 & -0.075 & -0.041 & 1.000 \\
& & & & & & & & & & \\
\hline
\end{tabular}




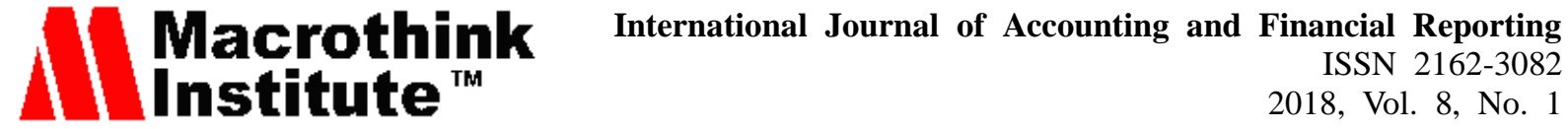
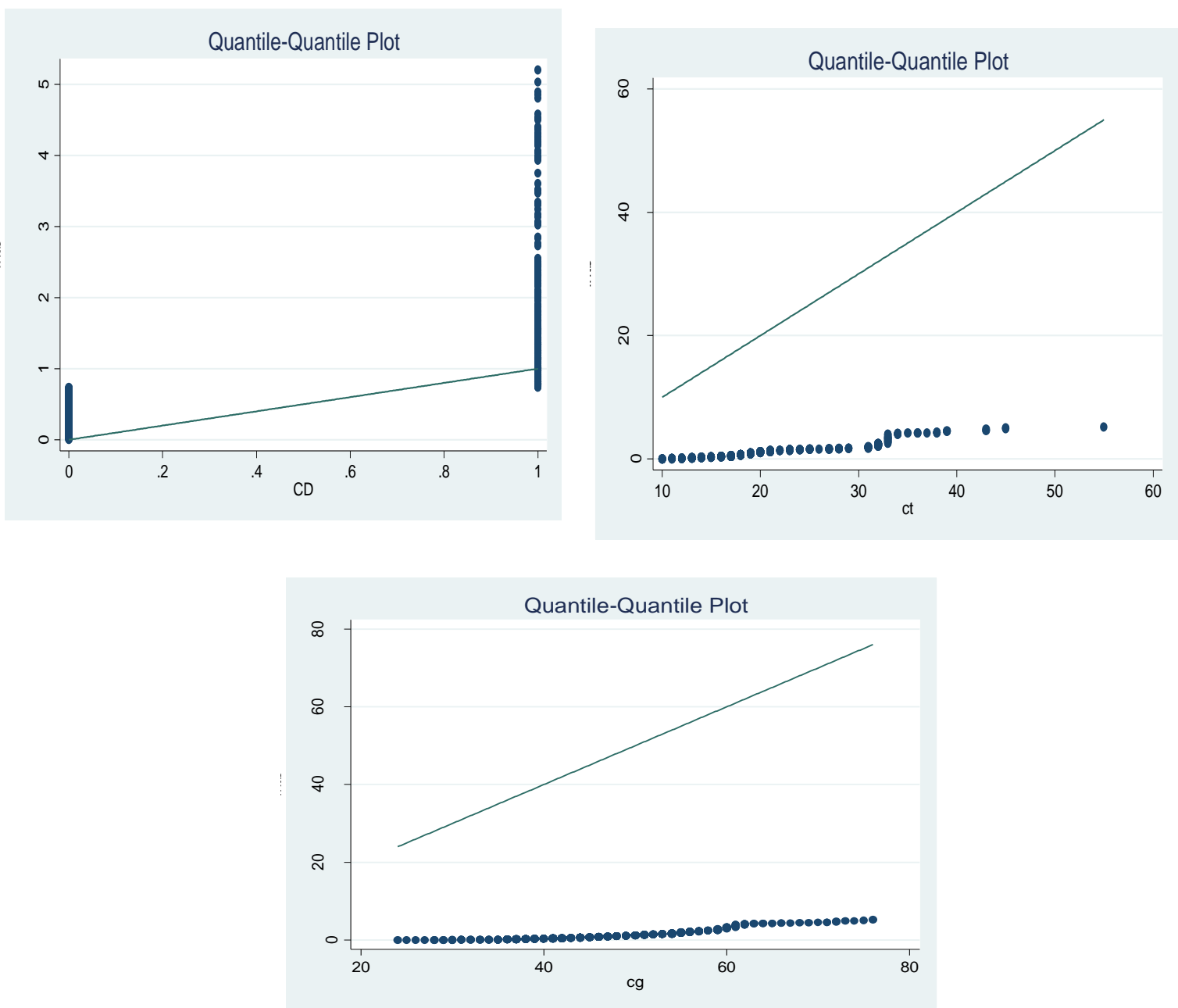

Figure 1. Quantile-Quantile plot of CEO tenure, CEO duality, and CEO age with the Tobin's Q

\section{Tobin's Q}

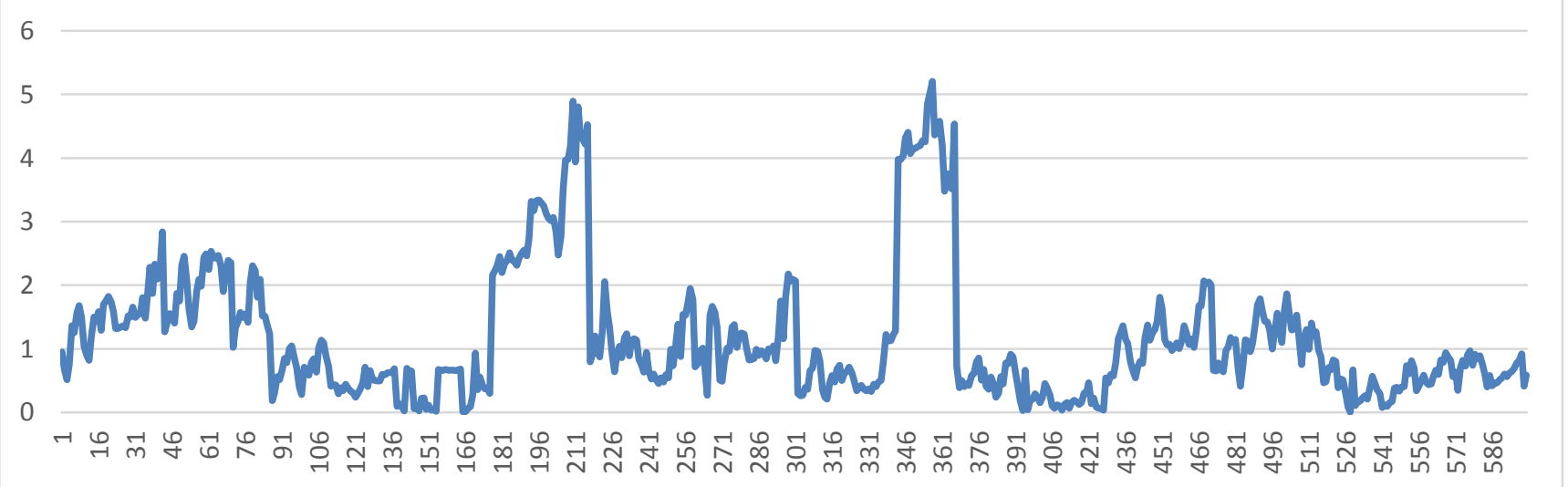

Figure 2. Tobin's Q ratio for all Organizations 


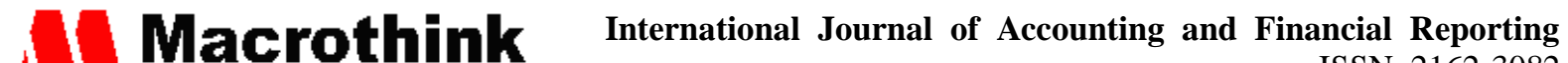 ISSN 2162-3082 2018, Vol. 8, No. 1}

\subsection{Multivariate Regressions}

Table 3 explains the regression results of the Tobin's Q on CEO and the organization characteristics. The OLS estimations show that CEO age and CEO tenure have negative and statistically significant influence on the firm valuation. More specifically, a one year rise in CEO age is related with a $0.60 \%$ decrease in Tobin's $\mathrm{Q}$ whereas one more year of CEO tenure is linked with a more decrease in Tobin's $Q$ about 3\%. The Quantile regressions expose that CEO age has a statistically significant influence on a firm valuation that is about the same through all quantiles. As compare the influence of CEO tenure is restricted on the Quantile at which it is assessed. The lower quantiles, CEO tenure seems to have no observable influence on a firm valuation. Therefore, this influence might be more and statistically significant in growth organizations. The results show that the influence of tenure is dependent on the growth opportunities facing an organizations, whereas the effect of CEO age is independent of the growth characteristics of the organizations. The stronger negative influence of CEO tenure for greater Q organizations recommends that the damaging influence of a longer serving CEO is more expensive for growth organizations than for mature organizations. The identical influence of age through the quantiles might be driven by "managerial characteristics, such as the individual elasticity and energy linked with the youth" that equally influence both growth and mature organizations.

CEO duality seems to have a greatly statistically significant influence on a firm valuation. The organizations where the CEO is also the chairperson of the board, the OLS results shows that Tobin's Q is $16.7 \%$ more than in firms where these two responsibilities are separated. This result is in line with the stewardship opinions that duality stimulates the strong organization headship (Finkelstein and Hambrick, 1996) and allows immediate reactions to outside tasks. Additionally, the Quantile regressions denote an extraordinary variation from low to high quantiles. In a low growth organization, the influence of duality is close to zero and also insignificant, but the effect rises consistently through the quantiles and at the $90^{\text {th }}$ percentile. It means the high growth organizations, the effect is twice as more as the one specified by the OLS regressions. Ramdani and Witteloostuijn (2010) also find a positive association among duality and return on assets that rises with the quantile of return on asset. As for as the together results, the Quantile regression shows that CEO age, tenure, and duality play an important role that what the OLS effects seems to recommend. More essentially, excluding for $\mathrm{CEO}$ age, they occur in high growth organizations more than in the low growth organizations whereas the importance in the economy is likely to decrease over the time period. This suggest that the real effects are expected to be more significant, meanwhile they restrain the progress of organizations whose encumbrance in the particular economy is probably to increase in the future.

The other empirical research work report the results for which the effects fluctuate according to the industry region. Henderson et al., (2006) confirmed that CEO tenure is positively associated to the firm's profitability in the food sector, but is negatively related with the firm profitability in the computer sector. The results of this study is consistent with their finding. The intention for the diverse effect on a firm valuation might be that the high growth firms, which are categorized by more Tobin's Q, usually require the CEOs who are willing to 


\section{Mll Macrothink}

International Journal of Accounting and Financial Reporting ISSN 2162-3082

encirclement new patterns and who are open to different new ideas. These quantiles tend to decrease with the tenure, it is anticipated that firms with long serving CEOs are categorized by lower the performance.

The results of the control variables are consistent with the results explained in the literature. The size of the board is inversely linked with the firm valuation, which is in line with the (Yermack, 1996; Nazir et al., 2016). It means that the members of group's might become less intricate in a strategic decision making, due to the co-ordination problems, which has the value of damaging the organization's ability to initiate the change of strategic. The board independence is linked with an insignificant effect by OLS, but it seems to have a positive effect at the higher quantiles. After all, the board ownership has a positive influence on the firm's valuations. All of these results is in line with the idea that stock ownership is favorable to the firm value (Bhagat and Bolton, 2008).

Table 3. Regressions results of CEO Characteristics on firm valuation

\begin{tabular}{|c|c|c|c|c|c|}
\hline Variables & OLS & Quantile R & essions & & \\
\hline & & 0.25 & 0.50 & 0.75 & 0.90 \\
\hline CEO age & $-0.0060(-1.12)^{* *}$ & $-0.0046(-2.17)^{* *}$ & $-0.0019(-2.99)^{* *}$ & $-0.0076(-1.10)^{* *}$ & $-0.0074(-1.23)^{*}$ \\
\hline CEO tenure & $-0.0331(-1.98)^{*}$ & $0.0057(0.13)$ & $-0.0083(-1.49)$ & $-0.018(-2.09)^{*}$ & $-0.017(-2.21)^{*}$ \\
\hline CEO duality & $0.1675(1.79)^{* *}$ & $-0.0014(-0.02)$ & $0.0298(1.99)^{* *}$ & $0.2061(1.59)^{* *}$ & $0.2787(1.43)^{*}$ \\
\hline Board Size & $-0.0148(-0.61)^{*}$ & $-0.047(-2.43)^{* *}$ & $-0.0422(-3.62)^{*}$ & $-0.0185(-0.44)$ & $-0.1803(-1.62)^{* *}$ \\
\hline Board Independence & $0.7716(1.01)$ & $0.6051(1.64)$ & $-0.1436(-2.34)^{* *}$ & $1.7867(2.08)^{*}$ & $1.3765(2.89)^{* *}$ \\
\hline Board Ownership & $0.0615(3.86)^{* * *}$ & $0.0298(2.33)^{* *}$ & $0.0713(3.63)^{*}$ & $0.1127(4.08)^{* * *}$ & $0.1494(2.06)$ \\
\hline Firm Size & $0.1640(7.69)^{* *}$ & $0.1490(5.13)^{* *}$ & $0.1205(9.89)^{*}$ & $0.1087(10.43)^{* *}$ & $0.1198(9.65)^{*}$ \\
\hline Leverage & $-0.8471(-2.87)^{* *}$ & $-0.5774(3.18)^{* *}$ & $-0.2409(-4.76)^{* *}$ & $-0.2871(3.32)^{* *}$ & $-0.1470(2.18)^{*}$ \\
\hline Constant & 0.7995 (1.39) & $0.4523(2.02)$ & $1.4953(1.43)$ & $0.6782(1.68)$ & $0.2181(1.98)$ \\
\hline $\mathrm{R}^{2} /$ Pseudo $\mathrm{R}^{2}$ & 0.2595 & 0.1678 & 0.1823 & 0.2011 & 0.2190 \\
\hline
\end{tabular}

Note: $* * *, * *$ and $*$ are $1 \%, 5 \%$ and $10 \%$ of significant levels, respectively.

\section{Conclusion}

This paper examines the effects of CEO characteristics on a firm valuation using a sample of Chinese firms over the period of 2007-2016. We consider the effects of three CEO characteristics that previous empirical work have shown to be essential elements of firm's valuation: CEO age, CEO tenure, and CEO duality. The CEO age and CEO tenure, the first paper to give complete indication on their effects on firm valuation. Moreover, the first study to examine the effects of these CEO characteristics using a Quantile regressions. The Quantile regression methodology permits us to perceive the distinction effects of some of the CEO characteristics on the firm valuation through the high and low growth firms, so giving 
new perceptions into the mechanism through which CEO characteristics influence the firm valuation.

The results show that CEO age is negatively linked with Tobin's Q, the performance measure, which means that the portfolio returns for organizations managed by the younger CEOs better perform those for organizations with older CEOs. This study also find that this effect does not fluctuate through mature and growth organizations. The CEO age and tenure shows a negative linked with the firm valuation. We find that the effects of CEO tenure fluctuate distinctly through growth opportunities: the effect is more prominent in high growth organizations and is irrelevant in low growth organizations. This recommends that the cost of conventionality of the long serving CEOs is small in mature low growth organizations and that the better experience and knowledge of the organization of such CEOs more than offset the possibly damaging effects of their greater conventionality. The cost of conventionality is more in vibrant growth organizations, and the match between an organization's atmosphere and its policies might decline as the CEO tenure rises, leading to a statistically negative influence on a firm valuation. The indication is that mature and growth firms aspect different costs and profits of CEO tenure foremost to different leading CEO tenures.

Finally, we contribute to the discussion on the effects of board headship on a firm valuation. According to the agency theory expects a negative effect, which is consistent by a number of empirical research work (Barker, 2002; Bhagat and Bolton, 2008). On the other hand, the stewardship theory suggests a positive effect which is supported by (Nazir et al., 2016). Our OLS regression results endorse a statistically significant positive association among CEO duality and firm valuation, supporting the stewardship theory. Furthermore, the Quantile regression expose that this relationship is significant only for higher quantiles of Tobin's Q. Whereas the duality might be complained on the ground that it obstructs the board's capability to observe the CEO and limits the board's supremacy to fire an incompetent CEO, it also accelerates the quick decision making. This is particularly essential in high growth organizations due to their quickly changing atmosphere; hereafter the stronger effect in the higher quantiles of the firm valuation. The assessments of the supervisory bodies are also divided on this issue: CEO duality is dispirited in the corporate governance codes. In the light of the corporate governance code recommendation, which is not favor of the CEO duality, but our results show that CEO duality is essentially related with better firm valuation in China, and also this is a positive effect is focused in the growth firms. At last this result highlights the importance of enlightening strategy which is endorsements by this empirical research.

This research will be helpful to the further researchers as it provided with good theoretical and practical implications of the variables under this study in the performance situation. Further research can examination by containing the role of the technology innovation to measure its influence along with the CEO characteristics on the organizations' valuation. 


\section{$\Lambda$ Macrothink}

International Journal of Accounting and Financial Reporting

ISSN 2162-3082

2018, Vol. 8, No. 1

\section{References}

Adams, R., \& Ferreira, D. (2009). Women in the boardroom and their impact on governance and performance. Journal of Financial Economics, 94(2), 291-309. https://doi.org/10.1016/j.jfineco.2008.10.007

Allegrini, G. (2013). Corporate boards, audit committees and voluntary disclosure: Evidence from Italian listed companies Journal of Management and Governance, 17(1), 187-126. https://doi.org/10.1007/s10997-011-9168-3

Barker, V. L. (2002). CEO characteristics and firm R\&D spending. Management Science, 48, 782-801. https://doi.org/10.1287/mnsc.48.6.782.187

Barontini, R., \& Caprio, L. (2006). The effect of family control on firm value and performance: Evidence from continental Europe. European Financial Management, 12(5), 689-723. https://doi.org/10.1111/j.1468-036X.2006.00273.x

Bhagat, S., \& Bolton, B. (2008). Corporate governance and firm performance. Journal of Corporate Finance, 14, 257-273. https://doi.org/10.1016/j.jcorpfin.2008.03.006

Boyd. (1995). CEO duality and firm performance: A contingency model. Strategic Management Journal, 16, 301-312. https://doi.org/10.1002/smj.4250160404

Byrd, J., \& Hickman, K. (1992). Do outside directors monitor managers? Evidence from tender offer bids. Journal of Financial Economics, 32(2), 195-221. https://doi.org/10.1016/0304-405X(92)90018-S

Child, J. (1975). Managerial and organizational factors associated with company performance-Part II. A contingency analysis. Journal of Management Studies, 12, 12-27. https://doi.org/10.1111/j.1467-6486.1975.tb00884.x

Daily, C. M. (1997). Sources of CEO power and firm financial performance: A longitudinal assessment. Journal of Management. https://doi.org/10.1177/014920639702300201

Davidson, W. N. (2007). The influence of executive age, career horizon and incentives on pre-turnover earnings management. Journal of Management and Governance, 11(1), 45-60. https://doi.org/10.1007/s10997-007-9015-8

Finkelstein, D. (1994). CEO duality as a double-edged sword: How boards of directors balance entrenchment avoidance and unity of command. Academy of Management Journal, 37, 1079-1108. https://doi.org/10.2307/256667

Finkelstein, S., \& Hambrick, D. (1996). Strategic leadership: Top executives and their effects on organizations. Nashville: TN: South-Western Publishing.

Finkelstein. (1994). CEO duality as a double-edged sword: How boards of directors balance entrenchment avoidance and unity of command. Academy of Management Journal, 37, 1079-1108. https://doi.org/10.2307/256667

Gibbons, M. (1992). Does executive compensation affect investment. Journal of Applied Corporate Finance, 5(2), 99-109. https://doi.org/10.1111/j.1745-6622.1992.tb00493.x 


\section{$\Lambda$ Macrothink}

International Journal of Accounting and Financial Reporting

ISSN 2162-3082 2018, Vol. 8, No. 1

Hampel. (1998). Final report of the committee on Corporate Governance. London: Gee.

Henderson, A. D. (2006). How quickly do CEOs become obsolete? Industry dynamism, CEO tenure, and company performance. Strategic Management Journal, 27(5), 447-460. https://doi.org/10.1002/smj.524

Hermalin, \& Weisbach. (1991). The effects of board composition and direct incentives on firm performance. Financial Management, 20(4), 101-112. https://doi.org/10.2307/3665716

Hirshleifer. (1993). Managerial reputation and corporate investment decisions. Financial Management, 22(2), 145-160. https://doi.org/10.2307/3665866

Jensen, M. (1983). The modern industrial revolution, exit, and the failure of internal control $\begin{array}{llll}\text { systems. } \quad \text { of } & \text { Finance, } & \text { 831-880. }\end{array}$ https://doi.org/10.1111/j.1540-6261.1993.tb04022.x

Johnson, D. (1997). Sources of CEO power and firm financial performance: A longitudinal assessment. Journal of Management, 76(2), 323-329.

Kang, E. Z. (2005). Board leadership structure and firm performance. An International $\begin{array}{llll}\text { Review } \quad \text { Corporate } & \text { Governance, } & \text { 785-799. }\end{array}$ https://doi.org/10.1111/j.1467-8683.2005.00470.x

Kim, S. S. (2016). Do CEOs exercise managerial discretion to save their jobs? Journal of Management and Governance, 20(1), 179-200. https://doi.org/10.1007/s10997-014-9300-2

Kitchell. (1997). CEO characteristics and technological innovativeness: A Canadian perspective. Canadian Journal of Administrative Sciences, 14(2), 111-121. https://doi.org/10.1111/j.1936-4490.1997.tb00123.x

Lorsch, J. (1989). Pawns and Potentes: The reality of America's Corporate Boards,. Harvard Business School Press, Boston, MA.

Mason P, H. D. (1984). The organization as a reflection of its top managers. Academy of Management Review, 9, 193-206.

Matta E, B. P. (2008). The accentuated CEO career horizon problem: evidence from international acquisitions. Strategic Management Journal, 29, 683-700. https://doi.org/10.1002/smj.680

McClelland, P. (2012). CEO career horizon and tenure: Future performance implications under different contingencies. Journal of Business Research, 65, 1387-1393. https://doi.org/10.1016/j.jbusres.2011.09.003

Miller, D. (1991). Stale in the saddle: CEO tenure and the match between organization and environment. Management Science, 37, 34-52. https://doi.org/10.1287/mnsc.37.1.34

Morck, S. V. (1988). Management ownership and market valuation: An empirical analysis. Journal of Financial Economics, 293-315. https://doi.org/10.1016/0304-405X(88)90048-7 


\section{MInstitute Macrothink $^{m}$}

International Journal of Accounting and Financial Reporting ISSN 2162-3082

Nazir, M., Zulfiqar, M., Saeed, M., \& Habib, Y. (2016). The Influence of Board Characteristics on Shareholders Assessment of Risk for Small and Large Firms: Evidence from Pakistan. International Journal of Economics and Financial Issues, 6(2), 596-606.

Park, G. (2002). Board leadership structure and CEO turnover. Journal of Corporate Finance, 8(1), 49-66. https://doi.org/10.1016/S0929-1199(01)00028-1

Ramdani, D., \& Witteloostuijn, A. (2010). The impact board independence and CEO duality on firm performance: A quantile regression analysis for Indonesia, Malaysia, South Korea and Thailand. British Journal of Management, 21, 607-626. https://doi.org/10.1111/j.1467-8551.2010.00708.x

Rechner, P. (1991). CEO duality and organizational performance: a longitudinal analysis. Strategic Management Journal, 155-160. https://doi.org/10.1002/smj.4250120206

Report, H. (1998). Final Report of the comittee on Corporate Governance. London: Gee.

Serfling, M. A. (2014). CEO age and the riskiness of corporate policies 25, 251-273. Journal of Corporate Finance, 25, 251-273. https://doi.org/10.1016/j.jcorpfin.2013.12.013

Solomon, W. (1993). Crises prevention: how to gear up your board. January-February, 68-75.

Stole, P. a. (1996). Impetuous youngsters and jaded old-timers:Acquiring a reputation for learning. Polit. Econ., 1105-1134.

Vroom, P. B. (1971). Relationship between age and risk taking among managers. Journal of Applied Psychology, 55(5), 399. https://doi.org/10.1037/h0031776

Weisbach, M. (1988). Outside directors and CEO turnover. . Journal of Financial Economics, 20, 431-460. https://doi.org/10.1016/0304-405X(88)90053-0

Yermack, D. (1996). Higher market valuation of companies with a small board of directors. Journal of Financial Economics, $40, \quad 485-211$. https://doi.org/10.1016/0304-405X(95)00844-5

Zahra, S., \& Pearce, J. (1989). Boards of directors and corporate financial performance: A review and integrative model. Journal of Management, 15(2), 291-334. https://doi.org/10.1177/014920638901500208

\section{Copyright Disclaimer}

Copyright for this article is retained by the author(s), with first publication rights granted to the journal.

This is an open-access article distributed under the terms and conditions of the Creative Commons Attribution license (http://creativecommons.org/licenses/by/4.0/) 